\title{
33. DETRITAL AND BIOGENIC SEDIMENT TRENDS AT DSDP SITES 280 AND 281, AND EVOLUTION OF MIDDLE CENOZOIC CURRENTS
}

\author{
Monty A. Hampton, Geology Department, University of Rhode Island, Kingston, Rhode Island
}

\begin{abstract}
Changes in ratios of detrital to biogenic sediments and in mean grain sizes of detrital grains of samples from DSDP Sites 280 and 281 reflect middle Cenozoic development of oceanic circulation on and near the southern edge of the South Tasman Rise. The South Tasman Rise, a continental block with quartz-mica schist basement, subsided in the late Eocene during the final stages of rifting between Australia and Antarctica, producing a shallow marine connection between the southeast Indian Ocean and the southwest Pacific Ocean. The oldest sediment on the southern part of the South Tasman Rise is a nearshore shallow marine breccia, which is overlain by lower-energy, deeper-water sediments with minor amounts of siltand sand-size detritals, reflecting subsidence of the South Tasman Rise below wave-base. Through the late late Eocene, detritals generally increase in abundance and coarseness, apparently in response to an increase in bottom current velocities across the rise. The current intensified, producing a disconformity spanning most of the Oligocene. In the late Oligocene, deposition of coarse-grained, detrital-rich sediments resumed on the southern part of the rise, but throughout the Miocene a distinct reduction in detrital sedimentation occurred with a concomitant increase in biogenic sedimentation.

The deep basin south of the rise received fine-grained, poorly sorted detrital sediments with little biogenic material through much of the middle to late Eocene. In the latest Eocene, biogenic sedimentation increased, reflecting less restricted, oceanic conditions in the basin. Neogene unconformity probably reflects the development of the deep-ocean connection between the southeast Indian Ocean and the southwest Pacific Ocean. This caused the intense current that previously was flowing over the relatively shallow rise to migrate southward into deep water, possibly in conjunction with the onset of the Antarctic Circumpolar Current.
\end{abstract}

\section{INTRODUCTION}

Regional geological and geophysical evidence suggests that the South Tasman Rise was the last continental link between Australia and Antarctica, as Australia moved northward from Antarctica (see chapters in this volume; and Weissel and Hayes, 1972). Consequently, the South Tasman Rise was the last barrier separating the southeast Indian Ocean and the southwest Pacific Ocean. Development of oceanic circulation between these two oceans was closely related to the separation of the rise from Antarctica.

DSDP Site 281 is located near the southern edge of the South Tasman Rise in 1591 meters of water, and Site 280 is located just south of the rise in 4176 meters of water (Figure 1). Sediment samples from these sites were studied in order to better understand the development of oceanic circulation in the vicinity of the rise. The relative abundances of detrital and biogenic sediments and the mean grain sizes of the detrital grains are presented here, along with discussion of their hydraulic implications.
The lithology and stratigraphy at Sites 280 and 281 are discussed in the appropriate Site Report chapters (Chapters 7, 8, this volume). Figure 2 shows the lithologic columns for these sites.

\section{METHODS}

Samples were analyzed from stratigraphic levels (Figure 2) at Sites 280 and 281 that were judged to give maximum information concerning the history of ocean currents at these sites. Lithologic units that record important, typically rapid events were sampled at intervals as close as $2 \mathrm{~cm}$, whereas more lithologically consistent, thick units were sampled at intervals up to 100 meters. Thus the samples are not uniformly spaced in each sequence.

Ten-cc core samples were dried and weighed, then acidized in $10 \% \mathrm{HCl}$ to remove (biogenic) calcite. The weighed residue was centrifuged in Bromoform (s.g. = $2.85)$ to separate light and heavy fractions. These fractions were weighed, and representative splits of each were mounted in Canada balsam on glass slides. The 


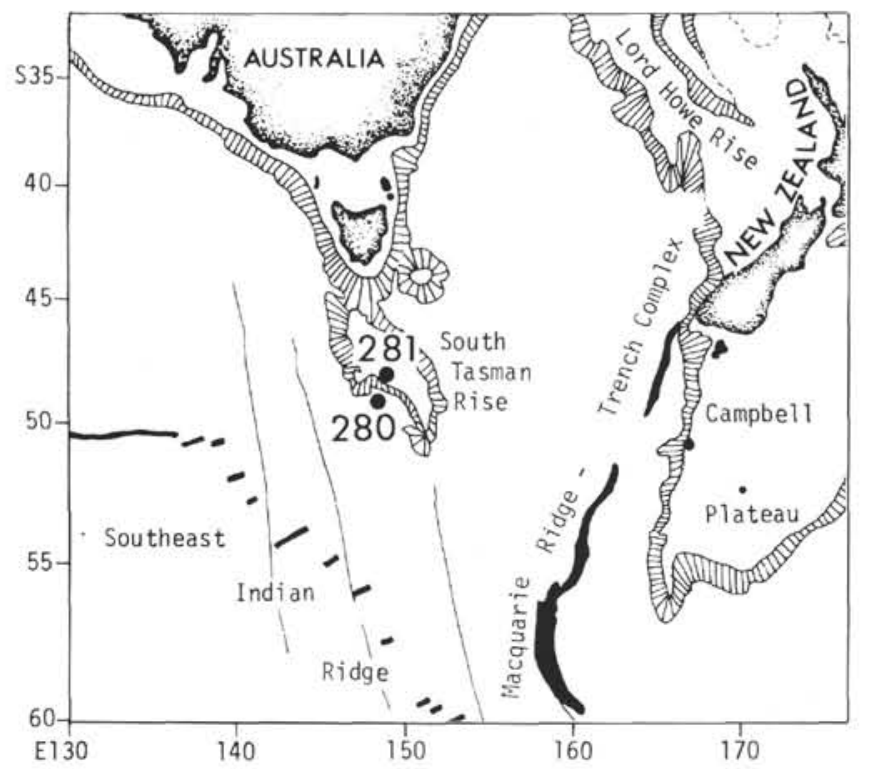

Figure 1. Locations of Sites 280 and 281.

following categories were counted in the light fractions: transparent detrital light minerals (mostly quartz and feldspar), glauconite, and biogenic silica. In the heavy fractions, transparent detrital minerals and opaque minerals were distinguished and counted. Approximately 200 detrital grains were counted in each grain mount.

The ratio of detrital sediment to biogenic sediment in each sample was calculated from the mineral-count data. The calculation was made by dividing the sum of the weight percentages of transparent light and heavy detrital minerals by the sum of the weight percentages of the biogenic silica and the $\mathrm{HCl}$-soluble biogenic carbonate. The opaque heavy minerals, some of which were authigenic, were arbitrarily excluded from the detritals in these determinations.

In the calculations, numerical abundances were transformed into weight percents by multiplying the average densities $(\mathrm{g} / \mathrm{cc})$ of the minerals in the various categories: detrital lights, $\rho=2.65$; glauconite, $\rho=2.50$; biogenic silica, $\rho=2.10$, detrital heavies, $\rho=3.30$; opaque heavies, $\rho=5.10$. These transformations were made so that the counts from the light and heavy splits, whose relative weights were known, could be combined, and that comparisons could be made to the weights of biogenic calcite. These transformations introduced some error because of the unequal volumes of the constituents; for example, sponge spicules typically have a greater volume than detrital grains, and therefore their weights are understated in the transformations.

Long axes of about 150 transparent light minerals were measured optically in each light-mineral mount, and logarithmic moment measures were computed from the grain-size data. Heavy minerals were examined in detail from Cores 13 and 14 at Site 281. Mineral species were identified and abundances were estimated. Heavy minerals were scanned in other samples at both Sites 280 and 281 .

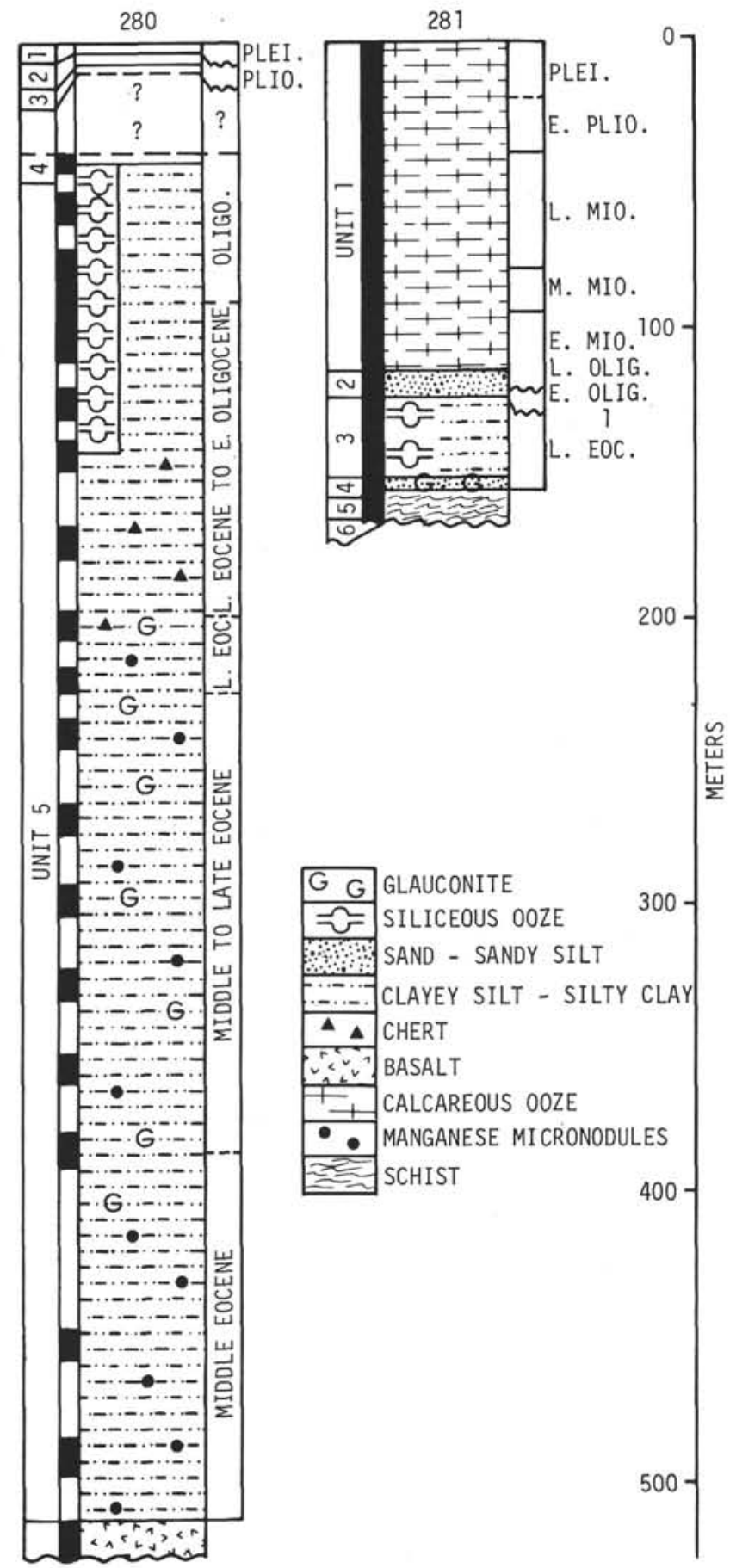

Figure 2. Columnar sections, Sites 280 and 281 .

\section{RESULTS}

The ratios of detrital to biogenic sediments and the mean grain sizes of detrital grains at Sites 280 and 281 are listed in Tables 1 and 2 and are graphically summarized in Figures 3 and 4. 
TABLE 1

Ratio of Detrital to Biogenic Sediments and Mean Grain Size of Detrital Grains - Site 280

\begin{tabular}{|c|c|c|c|c|}
\hline Sample & Age & $\begin{array}{l}\text { Depth } \\
\text { in } \\
\text { Core }(\mathrm{m})\end{array}$ & $\begin{array}{c}\text { Mean Grain } \\
\text { Size of } \\
\text { Detritals (phi) }\end{array}$ & $\begin{array}{l}\text { Ratio of } \\
\text { Detrital to } \\
\text { Biogenic Grains } \\
\text { (weights) }\end{array}$ \\
\hline $280-1-1-126$ & L. Miocene & 1.3 & 5.27 & 0.07 \\
\hline $280-1-3-50$ & L. Miocene & 3.5 & 3.85 & 5.76 \\
\hline $280-1-4-100$ & L. Miocene & 5.5 & 3.71 & 0.02 \\
\hline $280 \mathrm{~A}-1-1-142$ & Oligocene & 39.4 & 4.62 & 37.66 \\
\hline $280 A-1-2-6$ & Oligocene & 39.6 & 5.70 & 2.40 \\
\hline 280 A-1-4-90 & Oligocene & 58.9 & 5.56 & 1.54 \\
\hline $280 \mathrm{~A}-2-6-80$ & Oligocene & 61.8 & 5.34 & 2.99 \\
\hline 280 A-7-1-98 & $\begin{array}{l}\text { L. Eocene- } \\
\text { E. Oligocene }\end{array}$ & 121.0 & 5.06 & 17.35 \\
\hline $280 A-7-2-98$ & $\begin{array}{l}\text { L. Eocene- } \\
\text { E. Oligocene }\end{array}$ & 122.5 & 5.40 & 1.84 \\
\hline $280 \mathrm{~A}-7-4-103$ & $\begin{array}{l}\text { L. Eocene- } \\
\text { E. Oligocene }\end{array}$ & 125.5 & 5.31 & 2.16 \\
\hline $280 A-14-1-66$ & M-L. Eocene & 291.7 & 4.69 & 14.27 \\
\hline $280 \mathrm{~A}-18-1-110$ & M. Eocene & 406.1 & 4.42 & 45.67 \\
\hline $280 \mathrm{~A}-20, \mathrm{CC}$ & M. Eocene & 490.5 & 4.79 & 44.80 \\
\hline
\end{tabular}

SAMPLE
NUMBER
1, CC
3, CC
5, CC
7, CC
9, CC
11, CC
12, CC
$13-2,120$
$13-3,110$
$13-4,50$
$13-5,110$
$13-5,117$
$13-5,121$
13, CC (UP.)
13, CC (LOW.)
$14-1,32$
$14-2,70$
$14-3,90$
$14-4,80$
$14-5,100$
$14-6,90$
14, CC
$15-2,90$
$15-3,90$
15, CC
$16-2,60$
$16-3,90$
$16-5,100$
$16-6,90$
16, CC
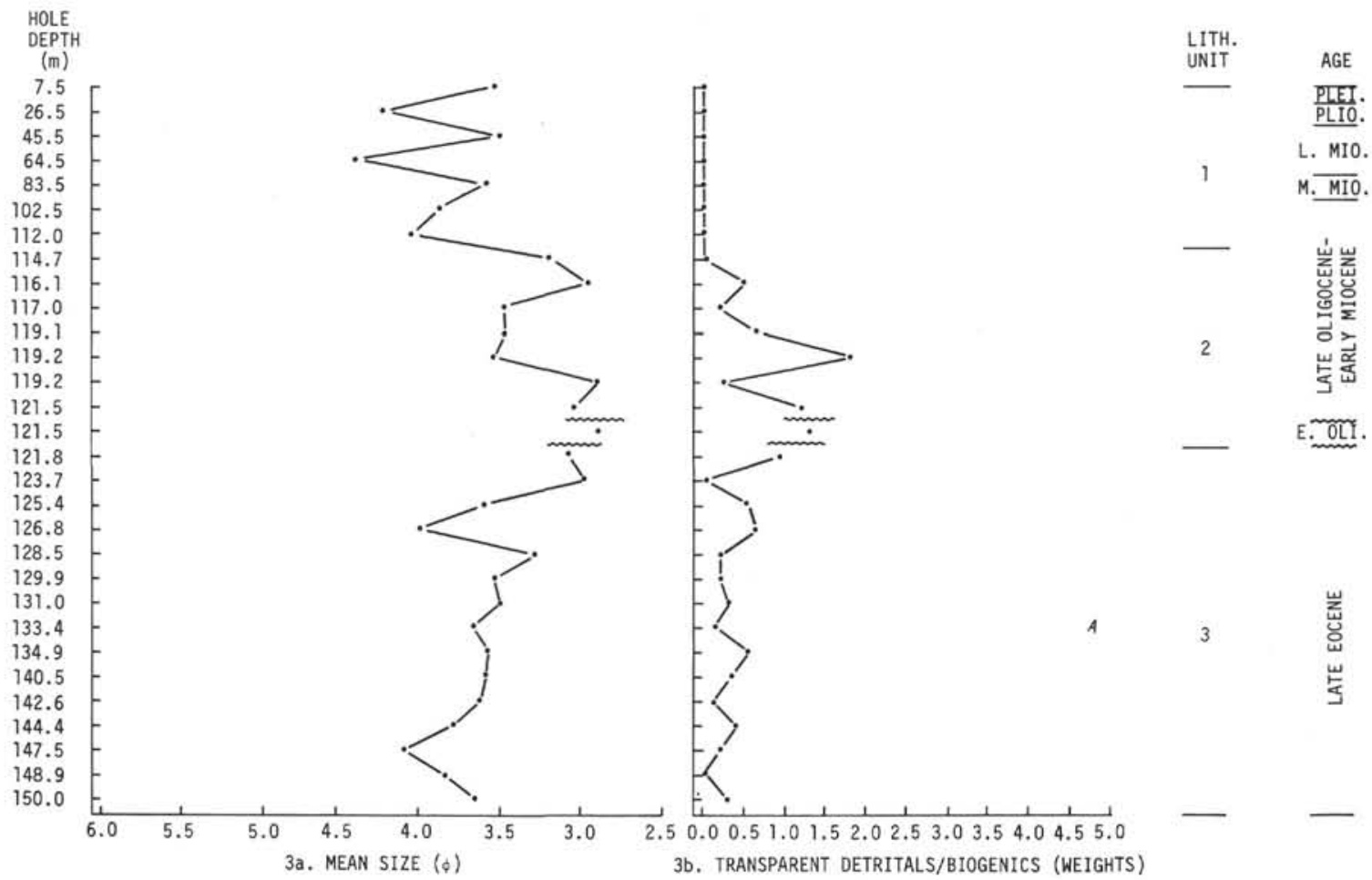

Figure 3. Detrital mineral data for Site 281.

Site 280 was not analyzed nearly as intensively as Site 281 , partly because of lack of time, but mainly because the interval of sediments most significant to this study is missing in the 32-meter uncored interval. For several reasons, caution must be used in interpreting the detrital/biogenic ratios at Site 280 and in comparing the ratios with those at Site 281: first, conditions of preservation of fossils are different at both sites; second Site
280 is in relatively deep water and probably was below the calcite compensation depth during deposition of the sequence, resulting in a paucity of calcareous microfossils throughout most of the section; and third, silica diagenesis may have caused postdepositional removal of siliceous biogenic matter from at least the middle part of Unit 5 at Site 280. The lower part of Unit 5 , however, also is low in siliceous microfossils and yet 
TABLE 2

Ratio of Detrital to Biogenic Sediments and Mean

Grain Size of Detrital Grains - Site 281

\begin{tabular}{|c|c|c|c|c|}
\hline Sample & Age & $\begin{array}{l}\text { Depth } \\
\text { in } \\
\text { Core }(m)\end{array}$ & $\begin{array}{c}\text { Mean } \\
\text { Grain } \\
\text { Size (phi) }\end{array}$ & $\begin{array}{c}\text { Ratio of } \\
\text { Detrital to } \\
\text { Biogenic Grains } \\
\text { (weights) }\end{array}$ \\
\hline $1, \mathrm{CC}$ & Pleistocene & 7.5 & 3.53 & 0.00 \\
\hline $3, \mathrm{CC}$ & Pliocene & 26.5 & 4.23 & 0.00 \\
\hline $5, \mathrm{CC}$ & L. Miocene & 45.5 & 3.49 & 0.00 \\
\hline $7, \mathrm{CC}$ & L. Miocene & 64.5 & 4.39 & 0.00 \\
\hline $9, \mathrm{CC}$ & M. Miocene & 83.5 & 3.58 & 0.00 \\
\hline $11, \mathrm{CC}$ & E. Miocene & 102.5 & 3.87 & 0.00 \\
\hline $12, \mathrm{CC}$ & E. Miocene & 112.0 & 4.05 & 0.02 \\
\hline $13-2-120$ & E. Miocene & 114.7 & 3.19 & 0.03 \\
\hline $13-3-110$ & E. Miocene & 116.1 & 2.94 & 0.53 \\
\hline $13-4-50$ & E. Miocene & 117.0 & 3.47 & 0.22 \\
\hline $13-5-110$ & E. Miocene & 119.1 & 3.46 & 0.69 \\
\hline $13-5-117$ & E. Miocene & 119.2 & 3.53 & 1.83 \\
\hline $13-5-121$ & E. Miocene & 119.2 & 2.88 & 0.22 \\
\hline $13, \mathrm{CC}$ (up) & E. Miocene & 121.5 & 3.04 & 1.23 \\
\hline 13, CC (low) & E. Oligocene & 121.5 & 2.89 & 1.32 \\
\hline $14-1-32$ & L. Eocene & 121.8 & 3.06 & 0.98 \\
\hline $14-2-70$ & L. Eocene & 123.7 & 2.97 & 0.09 \\
\hline $14-3-90$ & L. Eocene & 125.4 & 3.59 & 0.57 \\
\hline $14-4-80$ & L. Eocene & 126.8 & 3.98 & 0.68 \\
\hline $14-5-100$ & L. Eocene & 128.5 & 3.27 & 0.21 \\
\hline $14-6-90$ & L. Eocene & 129.9 & 3.53 & 0.23 \\
\hline $14, \mathrm{CC}$ & L. Eocene & 131.0 & 3.49 & 0.32 \\
\hline $15-2-90$ & L. Eocene & 133.4 & 3.65 & 0.15 \\
\hline $15-3-90$ & L. Eocene & 134.9 & 3.56 & 0.59 \\
\hline $15, \mathrm{CC}$ & L. Eocene & 140.5 & 3.58 & 0.39 \\
\hline $16-2-60$ & L. Eocene & 142.6 & 3.61 & 0.13 \\
\hline $16-3-90$ & L. Eocene & 144.4 & 3.78 & 0.43 \\
\hline $16-5-100$ & L. Eocene & 147.5 & 4.09 & 0.24 \\
\hline $16-6-90$ & L. Eocene & 148.9 & 3.83 & 0.06 \\
\hline $16, \mathrm{CC}$ & L. Eocene & 150.0 & 3.63 & 0.32 \\
\hline
\end{tabular}

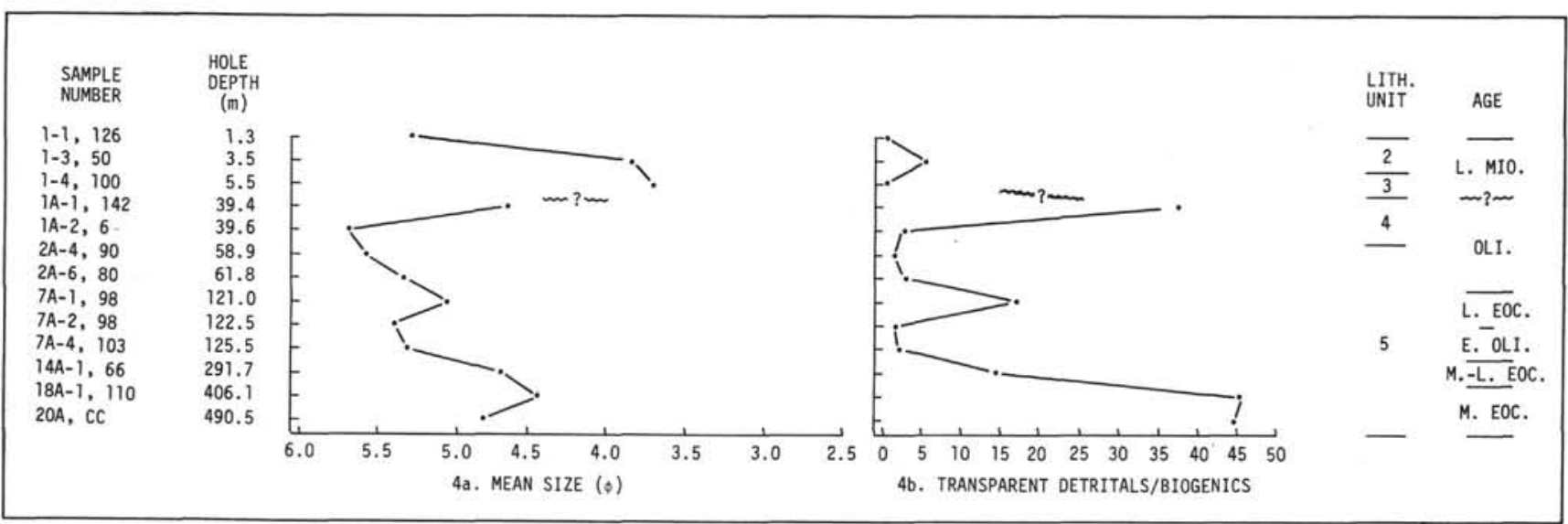

Figure 4. Detrital mineral data for Site 280.

does not contain chert or silica cement, suggesting an original lack of biogenic silica (Site Report Chapter 7, this volume). Site 281, in contrast, is in relatively shallow water, well above the calcite compensation depth, and does not show signs of silica diagenesis; therefore, the biogenic contents of the sediments probably reflect original biogenic deposition.
The heavy minerals in Cores 13 and 14 , Site 281, are a mixed suite containing abundant hornblende, tourmaline, zircon, epidote, and garnet, with less abundant to rare andalusite and kyanite. This suggests a dominant igneous, and a subordinate metasedimentary source. Traces of the metamorphic minerals sillimanite, staurolite, and periclase (?) also occur in some samples. 
A scan of the heavy-mineral slides of other samples revealed a dominance of hornblende, tourmaline, zircon, and garnet. Andalusite occurs rarely in some slides, but other metamorphic minerals were not observed.

\section{INTERPRETATION}

This interpretation is based mainly on the data in Tables 1 and 2 and the Leg 29 Site Reports (this volume).

The southern edge of the South Tasman Rise, at Site 281 , originally was a continental mass with schistose basement rock that foundered below sea level as Australia was making its final separation from Antarctica. Initial sedimentation, in late Eocene time, was under relatively high-energy conditions in shallow water as evidenced by the coarse-grained, poorly sorted angular schist breccia, and by a low-diversity, battered benthonic foraminiferal assemblage in Unit 5 (Figure 2).

The relatively fine-grained, biogenic-rich sediments of Unit 4 (Figure 2) indicate a reduction of current energy after initial subsidence, with deposition at neritic-upper bathyal depths. Thus, Unit 4 probably was deposited over the high-energy schist breccia as the South Tasman Rise subsided below wave-base.

Detrital analysis at Site 281 begins at the base of Unit 3 (Table 1, Figures 2, 3). Oceanic conditions at the beginning of deposition of Unit 3, in late Eocene time, were relatively quiet, involving mainly biogenic sedimentation, but with a low-velocity current depositing a few fine-grained detritals. These are essentially the same conditions outlined for Unit 4. Upward through Unit 3, the ratio of detritals to biogenics and the mean grain size of the detritals generally, though erratically, increase. This suggests an overall increase in current energy through the late Eocene. This current could have originated when the connection between the southeast Indian Ocean and the southwest Pacific Ocean, being generated by the continued subsidence of the South Tasman Rise, opened sufficiently to permit flow between the two water bodies. However, there also might have been some climatic influence. Shackleton and Kennett (this volume) give evidence for an abrupt cooling in these latitudes during the earliest Oligocene, and Kennett et al., (this volume) shows that this cooling profoundly increased global oceanic circulation.

Towards the end of the Eocene, a relatively highenergy current was moving across the rise, although conditions were still depositional as evidenced by the coarse grain size and high abundance of detritals at the top of Unit 3. Eventually the current increased to a transportational or erosional regime, producing the lower disconformity in Unit 2 (Figures 2 and 3). Current intensity temporarily waned during the early Oligocene to deposit glauconitic sand of similar grain size and slightly higher biogenic content than that present at the top of Unit 3, implying similar energy conditions. Then the current intensified to produce a major unconformity spanning much of the remaining Oligocene.

Deposition resumed in the late Oligocene producing more glauconitic sand containing abundant coarse- grained detritals (Unit 2). Successive deposits in Unit 2 show an overall decrease in grain size and an abundance of detritals, implying a decrease in current energy through most of the early Miocene. By late early Miocene this location on the rise was a site of quiet, dominantly biogenic sedimentation that still exists today. These quiet conditions are reflected in the late early Miocene to late Pleistocene sediments of Unit 1, with their low detrital/biogenic ratios.

The oldest sediments (Unit 5) at Site 280, in the deep water just south of the South Tasman Rise, are of middle Eocene age (Figure 2). These sediments rest on an intrusive basalt and are probably not much younger than true basement. Most of the sediments of Unit 5, until about late Eocene time, were deposited in a deep basin of restricted circulation. This is indicated by the scarcity of microfossils, the abundance of poorly sorted detritals, and the high organic content in the lower part of the unit. (The scarcity of microfossils may be due to solution and diagenesis.) This suggests that no free connection existed between the southeast Indian Ocean and the southwest Pacific Ocean at that time, which corresponds to the evidence at Site 281 .

Detrital sedimentation decreased in energy throughout the late Eocene and into the Oligocene. This is inferred from the general decrease in grain size of detritals throughout Unit 5 and into Unit 4 (Figure 4). A current was building on the South Tasman Rise (Site 281 , Unit 3 ) at this time, producing increasingly higherenergy detrital sedimentation and eventually the development of an Oligocene disconformity. Evidently, the current sweeping the rise was confined to that shallow area and was not sweeping the adjacent deep ocean floor. The deep area, in fact, was being cut off from a detrital source. Perhaps the current was preventing bypassing of sediments across the rise and into deep water. The conclusion is that subsidence and spreading had produced a shallow-water connection between the southeast Indian Ocean-southwest Pacific Ocean across the rise, but not a connection through the deep basin to the south.

Another possibility for the decrease in grain-size is that the main source of detritals for Site 280 at this time was Antarctica, which was slowly moving away. The heavy minerals from Sites 280 and 281 apparently are from similar source rocks, however, and Antarctica is not a likely source for Site 281 .

Judging from the probable original overall increase in siliceous microfossils at Site 280 upward through this same time period (Chapter 7, this volume), biogenic productivity increased as detrital sedimentation decreased. This implied development of open-ocean conditions, perhaps with significant upwelling. The conditions are probably due to the current on the rise, to climatic cooling, and/or incipient opening of this basin due to sea-floor spreading. The general increase in biogenic sedimentation is evident in Figure 4, but the absolute trend of these data may be controlled by diagenesis.

Miocene sediments at Site 280 were not recovered due to the 32-meter coring gap. However, the relatively large 
time span from late Oligocene to early Pliocene suggests that the Miocene sediments are highly condensed, or missing in an unconformity. This may record the opening of the deep-ocean connection between the southeast Indian Ocean and the southwest Pacific Ocean south of the South Tasman Rise, as the final continental separation occurred between Australia and Antarctica.

Figure 4 shows minimal evidence of current energy increase in the late Oligocene, by the (single-point) increase in mean grain size in Unit 4 just below the uncored interval. The increase apparently continues across the interval (Unit 3), then decreases through Unit 2. This trend corresponds to the analogous preceding situation at Site 281 from early Eocene through middle
Miocene time, going from below the disconformities to above. Possibly, during the late Oligocene to early Miocene the current on the rise moved from these relatively shallow depths into deep water in response to opening of a free deep-water connection between the southern Indian and Pacific oceans. This may record the onset of the Antarctic Circumpolar Current that flows in the Southern Ocean today.

\section{REFERENCE}

Weissel, J. K. and Hayes, D. E., 1972. Magnetic anomalies in the southeast Indian Ocean. In Hayes, D. E. (Ed.), Antarctic Oceanology II: The Australian-New Zealand Sector: Washington (Am. Geophys. UnionY, p. 165-196. 